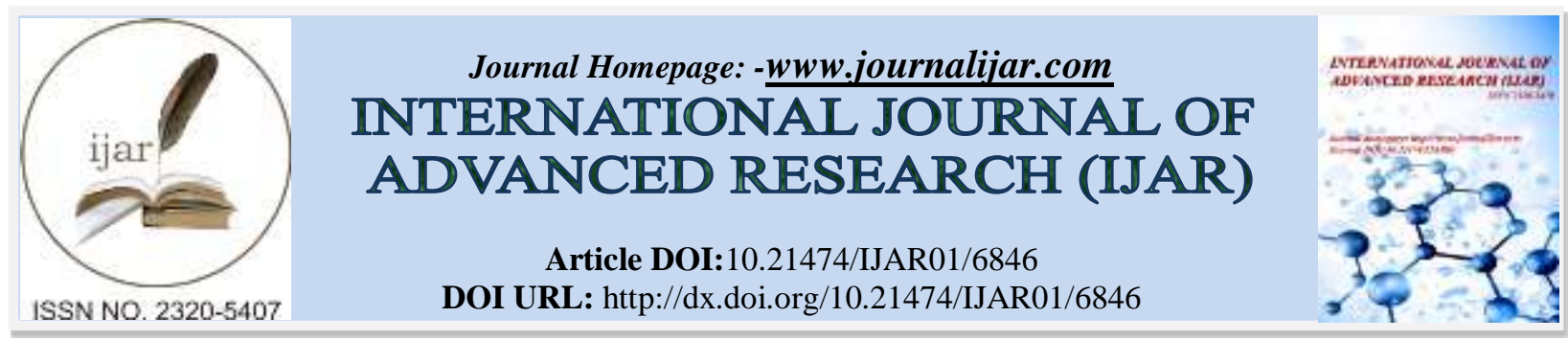

RESEARCH ARTICLE

\title{
IMPLEMENTATIONS OF LAW FIRMS FUNCTIONS AND DUTIES AS LOCAL GOVERNMENT'S LEGAL COUNSEL IN FACING LAWSUITS BEFORE THE COURT (STUDY IN GOVERNMENT OF SOUTH SULAWESI PROVINCE).
}

\section{Rina $^{1}$, Andi Pangerang Moenta ${ }^{2}$ and Hamzah Halim²}

1. Graduate School, Faculty of Law, Hasanuddin University.

2. Faculty of Law, Hasanuddin University.

\section{Manuscript Info}

Manuscript History

Received: 04 February 2018

Final Accepted: 06 March 2018

Published: April 2018

Keywords:-

Advocates, Court, Law Firms, Legal

Decision, Local Government.

\begin{abstract}
Based on the Decree of the Minister of Home Affairs Number 12 of 2014 concerning Guidelines on the handling of cases within the Ministry of Home Affairs and Local Government in Article 1 paragraph (2) on the handling of lawsuits within the Province carried out by the Provincial Law Bureau and Regulation of the Governor of West Sulawesi Number 40 Year 2016 Position, Duties and Functions, Organizational Structure and Working Procedures of the Regional Secretariat and Secretariat of the Regional Representative Council of the Province of West Sulawesi, In the face of the lawsuit the Law Firms uses the services of advocates/legal consultants from the first tribunal until there is a permanent legal decision so that the local government this Bureau of Justice monitors and facilitates the handling of cases. Then, the factors affecting the efforts of the West Sulawesi Provincial Government in facing the lawsuit, namely, the civil state apparatus resources are very lacking in the Law Firms and Human Rights Division and the facilities are still lacking and the funding is not in accordance with the activity program planning which is the inhibiting factor in the face of a lawsuit in court.
\end{abstract}

Copy Right, IJAR, 2018,. All rights reserved.

\section{Introduction:-}

West Sulawesi Province is a new province in Indonesia formed from the expansion of the province of south sulawesi, and has now become the 33rd province that was inaugurated since 5 October 2004 based on Law Number 26 of 2004 regarding the establishment of West Sulawesi province. The capital of West Sulawesi province is mamuju district, geographically this province is located in the cross position of the golden triangle of South Sulawesi, East Kalimantan and Central Sulawesi, and directly facing the national and international sailing route of Makassar Strait. ${ }^{1}$

Since the formation of the Province of West Sulawesi on 5 October 2004 based on Law Number 26 Year 2004 regarding the establishment of West Sulawesi Province, since then the implementation of government affairs

\footnotetext{
${ }^{1}$ Ministry of Home Affairs, regional profile of West Sulawesi Province, http://www.kemendagri.go.id/pages/ profil.daerah/provinsi/detail/6/sulawesi-barat accessed on September 5, 2017.
} 
according to the principle of autonomy and duty of assistance, the local government of West Sulawesi province is authorized to handle the affairs of his own government based on the Law -Indonesia Number 9 of 2015 concerning the second amendment to Law Number 23 Year 2014 on Regional Government.

The principle of a legal state requires, among other things, equal equity before the law that equality before the law is equal to every person in law and government, that is, recognized normatively and empirically. In the framework of this principle of equality, all discriminatory attitudes and acts in all its forms and manifestations are recognized as prohibited attitudes and actions, except for special and temporary measures called affirmative action to encourage and accelerate certain groups of citizens to pursue progress so as to achieve the same level of development and the equivalent of a much more advanced community group. ${ }^{2}$ Therefore, the Constitution also provides that everyone is entitled to equitable recognition, guarantee, protection and legal certainty and equal treatment before the law. ${ }^{3}$

Civil Servant who acts as the legal counsel of Regional Government authority is regulated in Law Number 9 Year 2015 concerning the second amendment to Law Number 23 Year 2014 regarding Regional Government, as regulated in Article 65 letter e which states that the regional head has duties and the authority to represent its territory within and outside the court, and may appoint a legal representative to represent it in accordance with the laws and regulations. In this case the Legal Bureau as part of the element of regional government may have the duty to run the government affairs in the field of law in accordance with the Regulation of the Minister of Home Affairs Number 12 of 2014 on Guidelines for Handling Cases in the Ministry of Interior and Local Government in Article 2 paragraph (2) reads the handling of legal proceedings in provincial environments by provincial law bureau. ${ }^{4}$

Implementation of local government directed to accelerate the realization of the welfare of the community through improving services, empowerment and participation of the community and improve the competitiveness of the region by taking into account the principles of democracy, equity, justice, privileges and peculiarity of a region in the system of the Unitary State of the Republic of Indonesia.

In the implementation of local government sometimes produces policies that in the opinion of some people violate the rights of a person or institution, so that the birth of the lawsuit, whether it is a lawsuit of State Administration or civil suit.

Government or state administration is one of the legal subjects. As a legal subject the government may take legal action, either in its capacity as a representative of the body or as an official. Government legal action may be an opportunity for the emergence of acts contrary to law, which violate the rights of citizens, the law must provide protection for the citizens of the country. The protection of this law is more emphasized on the legal protection of or acts of government law.

Legal Bureau is a local government agency located in the secretariat of the province of West Sulawesi which has the task of carrying out the analysis and preparation of legislation, documentation and provision of legal assistance, and has the function of analyzing and preparing the drafting of legislation and implementing documentation and information law, conduct assessment and legal defense and prepare legal aid materials and legal counseling. ${ }^{5}$

In essence, Civil Servants, in particular the Head of Legal Bureau and Legal Aid and Human Rights Division have the authority to provide legal assistance to the elements of local government that are involved in the case as stated in their main duties and functions.

On the Legal Bureau of Duties and Functions is not implemented in accordance with Law Number 9 Year 2015 concerning the second amendment to Law Number 23 Year 2014 on Regional Government and not in accordance with the elaboration of Regulation of Minister of Home Affairs Number 12 Year 2014 Article 2 paragraph (2) on the handling of lawsuits within Provinces carried out by the Provincial Law Bureau as well as the Elucidation of Governor Regulation of Number 40 of 2016 Article 18 concerning the Duties and Functions of the Legal Bureau,

${ }^{2}$ Jimly Asshiddiqie, Konstitusi dan Konstitusionalisme Indonesia, Konstitusi Press, Jakarta, 2005, p. 154.

3 Jimly Asshiddiqie, Op.Cit, p. 512.

${ }^{4}$ Regulation of the Minister of Home Affairs Number 12 of 2014.

5 BPKP, Main Duties and Functions of the Legal Bureau, http://www.bpkp.go.id/sesma/konten/176/Tugas-Pokokdan-Fungsi-Biro-Hukum.bpkp, accessed September 5, 2017. 
since the Regional Government Bureau of the province of West Sulawesi doesn't have a Civil State Apparatus in possession, Professional and Proportional in Courts, law firms also don't program Advocate Technical Guidance on an ongoing basis and don't send civil state apparatus to attend special training of local government attorney so that less active role in carrying out its duty and function.

In the case of local government is not handled directly by the State Civil Apparatus in this case the Legal Bureau but is handled by an Advocate/legal counsel or lawyer based on Law Number 18 Year 2003 regarding Advocate.

The Provincial Government of West Sulawesi in this case the Legal Bureau of each case of local government only facilitate the handling of the case using the services of lawyers/advocates or outside legal counsel, because the law firm in handling cases less professional in lawyer in court.

\section{Method of the Research:-}

The type of research used in this study is juridical-empirical legal research which is another term used in sociological law research and can be called also with field research. The juridical approach is used to analyze the various laws governing the Civil Service as the Legal Counsel of the Provincial Government of West Sulawesi within the scope of the judiciary. While the empirical approach is used to analyze not merely as a set of rules of law that is normatif mere, but the law is seen as the behavior of society. Individual field findings will be the main ingredient in revealing the problems studied by adhering to normative requirements.

\section{Results and Discussion:-}

Implementation of the Functions and Duties of the Legal Bureau as Legal Counsel of the Provincial Government of West Sulawesi Province in Facing the Claims.

\section{Preparing materials Legal Aid Considerations:-}

Preparing legal aid considerations is the duty of legal counsel to make an answer to a lawsuit containing the legal considerations that a judge can use to determine a decision. Preparing legal aid considerations is the duty of law firms in the legal and humanitarian assistance section of the legal dispute, where these legal aid considerations to resolve certain state, civil and criminal corporate law disputes through the judiciary.

Implementation of functions and duties of law firms in preparing legal aid considerations doesn't work in accordance with the elaboration of West Sulawesi Governor Regulation Number 40 of 2016 because the function of preparing legal aid considerations is carried out by lawyers/legal consultants in cooperation with the provincial government of West Sulawesi province.

The State Administrative Lawsuit addressed to the West Sulawesi Provincial Government is significant from year to year as illustrated in the following table:

Table I:-

\begin{tabular}{|c|c|c|c|c|}
\hline Number & Number/Date Case & Case Classification & The parties & Stages \\
\hline 1. & $\begin{array}{l}\text { 42/G/2017/P.TUN.Mks } \\
\text { June 8, } 2017\end{array}$ & $\begin{array}{l}\text { Staffing } \\
\text { Decree of the Governor of West } \\
\text { Sulawesi Number } \\
\text { 188.4/282/SULBAR /IV/2017 } \\
\text { regarding Honorarium and } \\
\text { Official Travel Expenses for } \\
\text { Chairman, Vice Chairman and } \\
\text { Member of Regional } \\
\text { Broadcasting Commission of } \\
\text { Indonesia Province of West } \\
\text { Sulawesi Fiscal Year } 2017 \text { Date } \\
21 \text { April 2017. }\end{array}$ & $\begin{array}{l}\text { Plaintiff: } \\
\text { 1. IDHAM, S.Sos } \\
\text { 2. NURUL ISLAM, M.Si } \\
\text { 3. SITI MUSTIKAWATI, } \\
\quad \text { SE } \\
\text { Defendant: } \\
\text { THE GOVERNOR OF } \\
\text { WEST SULAWESI }\end{array}$ & Appeal \\
\hline 2. & $\begin{array}{c}\text { 111/G/2016/PTUN.Mks } \\
\text { December 22, } 2016\end{array}$ & $\begin{array}{l}\text { Etc. } \\
\text { Decree of Governor of West } \\
\text { Sulawesi Number }\end{array}$ & $\begin{array}{l}\text { Plaintiff: } \\
\text { H. IRWAN HALIM } \\
\text { Defendant: }\end{array}$ & Decision \\
\hline
\end{tabular}




\begin{tabular}{|c|c|c|c|c|}
\hline & & $\begin{array}{l}\text { 188.4/686/SULBAR/XII/2016 } \\
\text { concerning Inauguration of } \\
\text { Dismissal of Members of } \\
\text { Regional Representative } \\
\text { Council of Regency of North } \\
\text { Mamuju named. H. IRWAN } \\
\text { HALIM December 9, } 2016 .\end{array}$ & $\begin{array}{l}\text { THE GOVERNOR OF } \\
\text { WEST SULAWESI }\end{array}$ & \\
\hline 3. & $\begin{array}{c}\text { 97/G/2013/PTUN.Mks } \\
\text { November 7, } 2013 .\end{array}$ & $\begin{array}{l}\text { Staffing } \\
\text { Decree of the Governor of West } \\
\text { Sulawesi Number } 688 \text { of } 2013 \\
\text { on the Inauguration of } \\
\text { Dismissal of Members of the } \\
\text { Regional House of } \\
\text { Representatives of Polman } \\
\text { Regency named RUSLAN } \\
\text { Dated October 18, } 2013 \text {. }\end{array}$ & $\begin{array}{l}\text { Plaintiff : } \\
\text { RUSLAN } \\
\text { Defendant: } \\
\text { THE GOVERNOR OF } \\
\text { WEST SULAWESI }\end{array}$ & Decision \\
\hline 4. & $\begin{array}{c}\text { 96/G/2013/PTUN.Mks } \\
\text { November 7, } 2013 .\end{array}$ & $\begin{array}{l}\text { Staffing } \\
\text { Decree of the Governor of West } \\
\text { Sulawesi Number } 670 \text { of } 2013 \\
\text { on the Inauguration of } \\
\text { Dismissal of Members of the } \\
\text { Regional House of } \\
\text { Representatives of Polman } \\
\text { Regency named H. A. } \\
\text { MAPPAUDA, S.Sos Date } 18 \\
\text { October 2013. }\end{array}$ & $\begin{array}{l}\text { Plaintiff: } \\
\text { RUSLAN } \\
\text { Defendant: } \\
\text { THE GOVERNOR OF } \\
\text { WEST SULAWESI }\end{array}$ & Decision \\
\hline 5 & $\begin{array}{c}\text { 07/G/2013/P.TUN.Mks } \\
\text { January 3, 2013. }\end{array}$ & $\begin{array}{l}\text { Staffing } \\
\text { Decree of the Governor of West } \\
\text { Sulawesi Number 465.a Year } \\
2012 \text { on the Inauguration of } \\
\text { Dismissal of Members of the } \\
\text { Regional House of } \\
\text { Representatives of Polman } \\
\text { Regency named H. ANDI. } \\
\text { MUHTADIN. M Date } 5 \\
\text { November 2012. }\end{array}$ & $\begin{array}{l}\text { Plaintiff: } \\
\text { RUSLAN } \\
\text { Defendant: } \\
\text { THE GOVERNOR OF } \\
\text { WEST SULAWESI }\end{array}$ & Decision \\
\hline
\end{tabular}

Source: The Youth Registrar of the Makassar State Administrative Court of 2018.

Based on the above table can be explained sitting case is:-

Whereas the object of the lawsuit in point 1 of Table I is: The Decree of State Administration in the form of Decree of Governor of West Sulawesi Number 188.4/282/SULBAR/IV/2017 concerning Honorable Honorarium or Honorarium and Official Travel Expense for Chairman, Vice Chairman and Member West Sulawesi Regional Broadcasting Commission for Fiscal Year 2017, dated 21 April 2017; Furthermore, as for the grace period on this lawsuit is; Whereas the Decision Letter of the Dispute Object was issued by the Defendant on 21 April 2017; That Decision is received / known to the Plaintiff On April 28, 2017 based on a copy of the letter of entry and the Office of the Governor through the Legal Bureau in the form of photocopies and received directly each Commissioner who previously Plaintiffs have known the information of the Decree and the Legal Bureau on its own initiative ; Whereas the a quo Lawsuit filed on June 8, 2017; Whereas therefore the a quo petition filed is still within the grace; 90 days in accordance with Article 55 of the State Administrative Judicature Law.

The Plaintiff feels aggrieved because the Minutes of Plenary Meeting of the Indonesian Broadcasting Commission of West Sulawesi province, Number: 485/01/ID-SB/I/2017 which should be the basis of issuance of the Governor's Decree is not used as a reference in the issuance process, the defendant seemed to copy copy paste ", The Decree of 2016, so that the Plaintiffs feel unaccompanied by their rights as Commissioners in accordance with Article 52 paragraph (1) of Regulation of the Indonesian Broadcasting Commission Number 01/P/KPI/07/2014" Plenary Meeting, as mentioned in letter a of this Regulation, is a meeting held periodically by the Broadcasting Commission 
of Indonesia to discuss matters relating to institutional issues and is the highest forum in decision making "and resulted in the issuance of Decree of Governor of West Sulawesi Number 188.4/282 /SULBAR/IV/2017 about Honorarium or Honorarium Remuneration and Office Travel Expenses For Chairman, Vice Chairman and Member a Regional Broadcasting Commission of Indonesia West Sulawesi Fiscal Year 2017 Date 21 April 2017, whereas beforehand had been held Plenary Meeting of Indonesian Broadcasting Commission of West Sulawesi province point:

1. Evaluation of Program and Performance of Regional Broadcasting Commission of Indonesia Year 2016 ;

2. Conducting Election of Chairman and Vice Chairman of Regional Indonesian Broadcasting Commission Based on Voting System as stated in the minutes ;

3. Substituting the Coordinator and Charging for the Regional Broadcasting Commission of West Sulawesi;

4. Making Chronologically Related to the Change of Chairman and Vice Chairman Time Term of Office 20172018.

Point 2 explains that a new Chairman and Vice Chairman have been elected and elected in accordance with Article 52 and Article 53 of the Regulation of the Indonesian Broadcasting Commission Number 01/P/KPI/07/2014 on the Institutionalization of the Indonesian Broadcasting Commission, then the result of the plenary meeting in notes in the Minutes of Plenary Session of the West Sulawesi Regional Broadcasting Commission Number: 485/01/ID-SB/ $\mathrm{I} / 2017$. And it is a necessity of the result of the plenary meeting to become a reference for the Defendant to issue a Decision Letter. However, in reality, the Defendant still made reference to the previous Decision Letter (Year 2016) to issue a Decree Year 2017; The subject of this lawsuit is :

Declare a Cancel or Unauthorized Decision of the State Administration in the form of: Decree of Governor of West Sulawesi Number 188.4/282/SULBAR/IV/2017 concerning Honorarium or Fixed Income and Travel Service Expense for Chairman, Vice Chairman and Member of West Sulawesi Regional Broadcasting Commission Year Budget 2017 Date 21 April 2017;

Requires the Defendant to immediately revoke the Decree of the Governor of West Sulawesi Number 188.4/282/SULBAR/IV/2017 on Honorarium or Honorarium Fixed Income and Official Travel Expenses for the Chairman, Vice Chairman and Member of the Regional Broadcasting Commission of Indonesia West Sulawesi Year 2017 Date 21 April 2017;

The issuance of the disputed object because the Plaintiff has been dismissed by the Nasdem Party as a member if the Plaintiff objected, in accordance with the provisions of Article 33 Paragraph (1) of Political Party Law Number 2 of 2011 shall first be resolved internally through the Nasdem Party Court, if the Plaintiff doesn't satisfied with the Decision of the Court The new party may file a lawsuit to the local District Court so that it is dismissel by the Chairman of the State Administrative Court of Makassar for having no legal basis.

Object of lawsuit in case point 2 Table I is Decree of the Governor of West Sulawesi Province Number: 188.4/686/SULBAR/XII/2016, Concerning Dismissal of Members of the Regional House of Representatives of North Mamuju Regency, dated December 9, 2016. The principal of the lawsuit declares null and void "The Decree of the Governor of West Sulawesi Province Number: 188.4/686/SULBAR/ XII/2016, Concerning Dismissal of Members of the Regional House of Representatives of North Mamuju Regency, dated December 9, 2016". The issuance of the object of the dispute since the Plaintiff has been dismissed by the Nasdem Party as a member if the Plaintiff objected, in accordance with the provisions of Article 33 paragraph (1) of Political Law Act No.2 of 2011 shall first be resolved internally through the Nasdem Party Court, if the Plaintiff not satisfied with the Decision of the Court The new party may file a lawsuit to the local District Court so that it is dismissed by the Chairman of the State Administrative Court of Makassar for having no legal basis.

Object of the lawsuit in the case at point 3 of Table I is the Decision of State Administration in the form of Decree of Governor of West Sulawesi Number: 670 Year 2013 Date 18 October 2013 About Inauguration of Dismissal of Members of People's Representative Council of Region Polewali Mandar Regency on behalf named is Ruslan.

Object of lawsuit in case point 4 Table I is the Decision of State Administration in the form of Decree of Governor of West Sulawesi Number: 668 Year 2013 Date 18 October 2013 About Inauguration of Dismissal of Members of People's Representative Council of Region Polewali Mandar Regency on behalf named is H. A. Mappauda AT, S.Sos. 
Object of lawsuit in case point 5 Table I is Decree of Governor of West Sulawesi Province Number $465 . \mathrm{a}$ Year 2012 concerning Inauguration of Dismissal of Regional Representative Council of Polewali Mandar Regency on behalf of H. Andi Muhtadin.M, dated 5 November 2012. Related to this matter correlates with the main tasks and functions of the Legal Bureau of the Regional Secretariat of West Sulawesi Province, especially the Legal Aid and Human Rights Division based on the Regulation of the Governor of West Sulawesi Number 40 Year 2016 regarding Position, Duties and Functions, Organizational Structure and Working Procedures of the Regional Secretariat and Secretariat West Sulawesi Provincial People's Representative Council, where one of its duties and functions is to provide legal / advocacy assistance to every State Civil Apparatus and Official in the provincial government to the case in the face of the investigation stage to the judicial body related to the execution of its duties.

Related to Preparing legal aid considerations, according to Bujaeramy Hassan (Head of Legal Bureau of West Sulawesi Provincial Secretariat), based on the author interview on Wednesday, January 10, 2018, he said that in preparing legal aid considerations during this time carried out in the form of making a note legal considerations, making official memorandum, reviewing the staff, conducting studies on legal issues involving the Civil State Apparatus and the Government within the scope of West Sulawesi Province and coordinating and consulting with lawyers / legal consultants in cooperation with the Government.

In connection with the State Administration's suits targeted to the Regional Government of West Sulawesi Province which is often the object of the lawsuit, based on the interview result of the Author with Andi Hasanuddin, as the Registrar of the Law at the State Administrative Court of Makassar (Tuesday, January 2, 2018) revealed that the Problem employment of the Dismissal of Members of the Regional People's Legislative Assembly which often leads to issues that eventually lead to the filing of a lawsuit in the Administrative Court.

As the Registrar of the Law at the State Administrative Court of Makassar, advising the Regional Government of West Sulawesi Province in the face of the lawsuit should be done by the Regional Government in this case the Legal Bureau as the Legal Counsel of the Provincial Government of West Sulawesi Province as it is considered to know in detail and clear the core of a case or lawsuit addressed to the Regional Government and considers that the problem arising is an internal matter in government.

Whereas the Attorney or Advocate from outside may be used his services in requesting advice and legal opinions in Civil and Criminal Pages in the District Court. Future expectations for the Legal Bureau to further enhance the craft in attending any sessions held by the Makassar State Administrative Court related to the lawsuit faced by the Provincial Government of West Sulawesi so that the trial proceeded smoothly and completed on time. The relationship of function theory to preparing the legal aid consideration is one of the functions of the Legal Bureau as the Legal Counsel of the Provincial Government of West Sulawesi Province In the face of the lawsuit in court but not in accordance with the theory of function and the elaboration of the Regulation of the Governor Number 40 of 2016 because this function is run by an advocate or government legal counsel.

\section{Providing Legal assistance:-}

Providing legal assistance is to provide a defendant's defense of a lawyer, when his case is examined in a preliminary hearing or in the process of examining his case before the court.

Legal Bureau in performing its duties and duty to provide legal assistance to the handling of cases and assistance Civil State Apparatus Provincial Government of West Sulawesi by getting orders from the leadership in this case the Governor or the Secretary of the Region in the settlement in cooperation with the provincial legal counsel as the decision letter of appointment of legal counsel in this case the law firm coordinates with the relevant regional apparatus unit or related parties to the legal issues faced and coordinates the legal consultant in handling issues in the court proceedings.

In reality, however, every case is not handled directly by law firms, but is handled by lawyers / legal consultants from the process of replicating the lawsuit up to the verdict so that the Legal Bureau doesn't play an active role in the handling of cases. Therefore, the West Sulawesi Provincial Legal Bureau doesn't have a professional state civil apparatus in the courts. At the Legal Bureau the function of providing direct legal assistance is to provide assistance in the investigation process and investigation of criminal cases conducted by the governor / deputy governor of West Sulawesi Province. 
Related to providing legal assistance, according to Bujaeramy Hassan (Head of Legal Bureau of West Sulawesi Provincial Secretariat) based on author interviews on Wednesday, January 10, 2018, he said that in providing legal assistance involving State and Government Civil Apparatus within the scope of Sulawesi Province West has been handled to Advocates / legal consultants who work with the Government so that in providing legal aid the firm is less active, due to the many important and urgent tasks in the Legal Bureau that must be resolved.

\section{Monitor and Evaluate the Program of Legal Aid and Human Rights Activities:-}

Monitoring and evaluating the program of legal and human rights assistance activities is a process of determining the value of an activity, policy or program whilst accomplished.

Monitoring and evaluating a temporary activity, policy or program, according to Bujaeramy Hassan (Head of Legal Bureau of the West Sulawesi Provincial Secretariat) based on author interviews on Wednesday, January 10, 2018, he said that the Legal Bureau monitors and evaluates every program of activity and policies implemented through several stages: the planning stage of activities, the implementation of activities and reporting activities.

Number of planned programs planned by the Legal Bureau of the West Sulawesi Provincial Secretariat Particularly the Legal Aid and Human Rights Division but after going through several stages so as to reduce the activities based on the available budget and carry out the activities deemed necessary to be implemented.

\section{Resolving a Legal Dispute:-}

Resolving legal disputes is a method of settling out of court by means of consultation, negotiation, mediation and conciliation. According to Rustam Timbonga, as Advocate / Legal Consultant, based on the interview result of the writer (on Thursday, January 11, 2010), said that the cause of West Sulawesi Provincial Government is often in lawsuit that is related to policy, sometimes not prudent in making decisions that affect the existence of the parties who feel disadvantaged, and the level of legal awareness of the community is increasing, so if people feel harmed, they use the legal path by filing a lawsuit to the court to resolve the problem.

The advice and wishes to the Legal Bureau in facing the lawsuit in court is much better to use Advocates / Legal Consultants than to go on their own in the trial, because much time and energy will be confiscated in court proceedings if the law is direct.

\section{Factors Affecting the Legal Efforts of the Provincial Government of West Sulawesi in Facing the Claims:- Empowering Civil State Officials Apparatus:-}

Empowering State Civil Apparatus is an effort to improve the capability and potential possessed by State Civil Apparatus, so as to realize the identity, dignity and dignity maximally to survive and develop themselves independently, qualified, invoative, creative and professional.

The steps that must be taken by the Bureau of Law in improving the ability and potential of the State Civil Apparatus of quality that is :

1. Handling or involving the Civil State Apparatus participates in the Special Training of Local Government Legal Counsel.

2. Giving scholarship of study duty to State Civil Apparatus based on the required discipline.

3. Carry out the activities of the Legal Counsel Technical Guidance continuously by involving law enforcers such as judges, prosecutors and lawyers.

4. Budgeted training fund of technical guidance and training of law authority of local government.

5. Giving trust to the State Civil Apparatus to carry out their duties independently and responsibly.

Based on the interviews of the author with Bujaeramy Hassan, Head of Legal Bureau of West Sulawesi Provincial Secretariat (Wednesday, January 10, 2018), according to him, one of the factors that caused the West Sulawesi Provincial Government is more likely to use Advocates / Konsultasn Hukum Local Government Legal Counsel, due to Human Resources which is considered still not good in terms of quantity and quality and doesn't have the capability to be entrusted to represent the Regional Government as a Legal Counsel, besides that he added that the policy pursued by Local Government so far should be changed by empowering the Apparatus Civil State in the ranks of West Sulawesi Provincial Government, Particularly in the Legal Aid and Human Rights Division, Increasing human resources by sending the State Civil Apparatus following the Training of Local Government Legal 
Counsel as well as implementing Tech Guidance attorney continuously, so that later can carry out Duties and Functions are Independent, Active, Creative, Innovative, Proportional and Professional.

Separately, the author also interviewed with Yustinus, as Head of the Legal Aid and Human Rights Assistance Division of the Legal Bureau of the West Sulawesi Provincial Secretariat (Wednesday, January 10, 2018), he said that Human Resources in the Legal Aid and Human Rights Division, in terms of quality is still very less and greatly affect the Regional Government is more likely to use the services Advocate / Legal Consultant as a legal representative than the existing Civil State Apparatus. From the aspect of quantity of Human Resources owned by the Legal Aid and Human Rights Division can be seen from the number of civil apparatus of the State especially those having the discipline of Law Science. As in the following table:

Table II:-

\begin{tabular}{|l|l|c|}
\hline \multicolumn{1}{|c|}{ Education } & \multicolumn{1}{|c|}{ Number of Employees } \\
\hline 1. & Bachelor of Law & 7 People \\
\hline 2. & Bachelor of Economics & 1 People \\
\hline 3. & Bachelor of Social & 1 People \\
\hline 4. & Senior High School & 1 People \\
\hline & Amount & 10 People \\
\hline
\end{tabular}

Source: Legal Bureau of Legal Aid and Human Rights Division of West Sulawesi Provincial Secretariat Year 2018.

Based on the above table it can be seen that the State Civil Apparatus from the discipline of Law Science as many as 7 (seven) people, the discipline of Economics as much as 1 (one) person, the discipline of Social Sciences 1 (one) person and high school graduates as much as 1 (one) person. This proves that the number of Apparatus in the Legal Aid and Human Rights Section has not met the optimal limit when compared with the existing workload.

\section{Sufficient Facilities:-}

Sufficient facilities are a means of supporting the success of a process of efforts undertaken in the public service, because if these two things are not available then all activities undertaken can not achieve the expected results in accordance with the plan.

In relation to adequate facilities, according to Bujaeramy Hassan, (Head of Legal Bureau of West Sulawesi Provincial Secretariat), based on the interview of the author on Wednesday, January 10, 2018, he said that facilities at the Legal Bureau are available and adequate such as laptop, computers, work tables, chairs, vehicles and so on, but from year to year facilities are damaged so that in the store and currently still use the facilities that are separated and have not held a new item or facility in law firm so that the functions and tasks can not be implemented maximally.

The effort taken by the law firm to overcome the problem of adequate facilities is budgeting the procurement of goods in the form of desks, chairs, laptops, computers and operational vehicles, and keep doing the maintenance of these assets, short-term benefits that can be used to perform the function and the duty of the law firm to proceed as expected whilst its long-term benefit is that the Legal Bureau has assets or goods that can be used until years to come.

\section{Adequate Funding:-}

Adequate funding is a process of providing funds that are run for the smooth running of an activity required a budget. Efforts taken by the Provincial Government of West Sulawesi Provincial Legal Bureau of adequate funding is programming the budget activities in accordance with the needs for the smoothness of the planned program activities.

The condition of funding at the Legal Bureau of West Sulawesi Provincial Secretariat so far is the existence of disbursement of funds that are not in accordance with the budget post because of activities that are never planned and urgent but must be implemented because of the leadership policy there are also activities that have been planned but the budget it is still insufficient to enforce the activity so that it uses funds from other activities to cover the shortfall. 
The Legal Bureau of the West Sulawesi Provincial Secretariat should be able to use the budget or funds in the current year in accordance with the program of activities and be accountable under existing rules, and carry out all activities that have been programmed without any refunds so that the budget body considers the Legal Bureau to manage the funds well so that in the next year get additional funds as needed.

According to Bujaeramy Hassan, (Head of the Legal Bureau of the West Sulawesi Provincial Secretariat), based on author interviews on Wednesday, January 10, 2018, the Funding Law Bureau is a factor affecting the implementation of its functions and duties in facing the lawsuit, which costs much handling cases such as advocate/legal consultant fees, court fees, official travel expenses, transportation costs and others.

The cost or budget for the handling of cases and funds to increase the resources of civil state apparatus is also still very less because the province of West Sulawesi is a new province so that the budget is in use for the cost of building public infrastructure such as roads and bridges, office buildings and others etc.

Effectiveness theory according Soerjono Soekanto on factors of facilities and legal facilities including adequate funding. because that is, in addition to supporting facilities, including highly educated and skilled manpower, adequate and sufficient finances to facilitate the implementation process of functions and duties of law firms as local government legal counsels in the face of lawsuits.

\section{Conclusions:-}

Implementation of the Functions and Duties of the Legal Bureau as Legal Counsel The local government of West Sulawesi Province runs less in line with the elaboration of the Decree of the Minister of Home Affairs Number 12 of 2014 on Guidelines for handling cases within the Ministry of Home Affairs and Local Government in Article 1 paragraph (2) on the handling of legal cases in Provincial Bureau shall be implemented by Provincial Law Bureau and Regulation of the Governor of West Sulawesi Number 40 Year 2016 concerning Position, Duties and Functions, Organizational Structure and Working Procedures of the Regional Secretariat and Secretariat of the Regional Representative Council of the Province of West Sulawesi, In the face of the lawsuit of the Legal Bureau using the services of advocates / consultants law, because the State Civil Apparatus at the Legal Bureau in terms of quantity is still lacking, in terms of law science in court is also very less qualified, less active and less professional in facing the lawsuit so using the services of lawyers or legal consultants in handling cases, the first level until there is a permanent legal decision so that the local government in this case the Legal Bureau only monitor and facilitate in handling cases.

Factors affecting the legal effort of the West Sulawesi Provincial Government in the face of the lawsuit are, the resources of the state civil apparatus are severely lacking in the Legal Aid and Human Rights Division, ideally 18 people in which each sub-division has five staff for the tasks in the Legal Aid section can be well accommodated, facilities are still lacking and funding is not in accordance with the program planning activities which is a factor inhibiting the face of lawsuits in court.

\section{References:-}

1. Aminuddin Ilmar, Hukum Tata Pemerintahan, Prenadamedia Group, Jakarta, 2013.

2. Andi Pangerang Moenta dan Syafa'at Anugrah, Pokok-Pokok Hukum Pemerintahan Daerah, PT. Raja Grafindo Persada, Depok, 2017

3. Andi Sifyan dan H. Abd. Asis, Hukum Acara Pidana Suatu Pengantar, Prenadamedia Group, Jakarta, 2014.

4. A. W. Paton, A Textbook Of Jurisprudence, English Language book Sosiety, Oxford Univercity Press, London, 1972.

5. Goldberg, Stephen B., Frank E, Sander, Nancy H. Rogers dan Sarah Rudolph Cole, Dispute Resolution Negosiation Mediation \& Other Processes (Aspen 6th et. Forthcoming).

6. Jimly Asshiddiqie, Konstitusi dan Konstitusionalisme Indonesia, Konstitusi Press, Jakarta, 2005, hal. 154.

7. Muhammad Djafar Saidi, Hukum Keuangan Negara, Edisi Revisi, PT. Raja Grafindo Persada, Jakarta, 2011.

8. Philipus M. Hadjon, Perlindungan Hukum Bagi Rakyat Indonesia, Bina Ilmu, Bandung, 1987.

9. http://www.kemendagri.go.id/pages/profil.daerah/provinsi/detail/6/sulawesi-barat. 